\title{
Status of Compliance to Dole-Department order 174 of Selected Fast food Establishments in Cabanatuan City, Philippines
}

\author{
Lyka Mae Fajardo, Marieta Corpuz, Paul David Mariano, Arnold Aguinaldo, \\ Felipe Balaria Jr.
}

\begin{abstract}
This research paper determined the status of compliance to the Department of Labor and Employment (DOLE) Department Order (D.O.) 174 of selected fast-food establishments in Cabanatuan City, Nueva Ecija, Philippines. The researchers find this important, especially to the large fast-food corporation, as this will be able to eliminate possible penalties that the DOLE may impose on them once proven violating the said D.O. with regards to labor contractualization. The methodology used in this research is an evaluative-descriptive survey with a guided questionnaire as the main instrument. The study involved 15 purposively chosen respondents. Findings of the study indicated that some of the fast food restaurants in Cabanatuan were still non-compliant to some of the requirements under D.O. 174. This stemmed from duplication of work between regular employees and $3^{\text {rd }}$ party employee arising from the agency, in terms of directing and controlling $3^{\text {rd }}$ party employees as stated in the DOLE Department order which prohibits the principal on direct involvement for non-regular employees. The study recommends that the management of selected fast-food establishments should conduct a thorough review of the content of Department Order-174 and develop and empower their team leaders through capability building programs so that they will be firm in their designation and can perform theirduties and responsibilities effectively.
\end{abstract}

Keywords- Business, compliance, DOLE Department 174, fast-food establishments, status.

\section{INTRODUCTION}

Contractualization has been a system long practice by a lot of companies in the country, especially large companies who want to keep their profits up. In the Philippine context, contractualization "is a work arrangement whereby workers are only hired for about five months without security of tenure, monetary, non-monetary and social protection benefits."The amendment of the Phil. Labor Code, which is more commonly known as Herrera Law [1].Contractualization of labor in the Philippines weakens the traditional power and concept of the unions (Macaraya, 1997). With the Philippine membership to the World Trade Organization, contractualization was used to attract the investor in the form of a huge army of cheap, docile labor [2]."Endo contractualization" refers to a short term employment practice in the Philippines, it is a form of contractualization which involves companies giving their workers temporary employment that last less than six months, while "5-5-5-" refers to contractual workers that are terminated after five months, and then rehired again for another five months or repeated hiring of contractual workers [3]. It is noted that Labor Code mandates the employers have to regularize the employee once the emp loyee has completed a six-month continues work. Thus, at then of the fifth month, employees' contract is terminated, where the employee will be asked not to report for a day or two, which will them be proceeded with another five-month contract. The Department of Labor and Employment ("DOLE") has long defined "endo" as a hiring practice deliberately resorted to prevent workers from acquiring regular status done through repeated short-term arrangements by one principal through the same or difference contractors [4]

Consistent with President Rodrigo Duterte's campaign promise to end fixed-term employment, more commonly known as "endo", the Department of Labor and Employment ("DOLE") launched a review of Department Order ("D.O."). In the interim, before the is suance of a new order, the DOLE released two issuances on 25 July 2016:D.O. No. 162, series of 2016.

Labor-only contracting, which is prohibited, refers to an arrangement where the contractor or subcontractor does not have substantial capital. The contractor or subcontractor does not exercise the right to control the performance of the work of the employee." [5]. 
Under the Philippine Labor Code, the legitimate labor contractors are the employer of the workers. The relationship between these two is also covered by the labor code. In the thriving industry of subcontracting, the manifold rights of the workers are increasingly being violated [6].

To end 'endo."' The marching order to end the contractualization is not an easy task to undertake. The problem of endo involves three parties in general: the enterprise that uses the labor; the labor service supplier who hires and supplies the labor; and the laborers who are hired. Under the current setup, as contractualization has developed, the company using the labor is not the direct hirer of the worker. The enterprise in need of labor services uses the labor service provider to hire workers. By using the labor service provider, the productive enterprise develops no direct employer-employee relationship with the worker [7]

In this study, the researchers attempted to describe the status of compliance of selected fast food establishment in Cabanatuan to the DO 174.Specifically, it aimed to determine theprocess of acquiring employees andthe current employment status of selected fast-food establishments in Cabanatuan City after the implementation of DOLE Department Order 174. Like wise, it described the duties and responsibilities of different types of employees and the challenges encountered by the company during the implementation of DO 174. The first-hand knowledge and personal experience of the respondents would shed light on the problem posed herein.

\section{METHODOLOGY}

This study used a quantitative type of research wherein current practices in terms of employment is compared with the requirement stated under Department Order 174 to determine the compliance of selected fast-food establishments. A total of 15 purposively chosen employees of selected fast-food establishments served as respondents of thisstudy. They were chosen purposively based on the following criteria [8]: they have prior learning or knowledge on DOLE Department Order 174, and they were directly hired, which belonged to the middle-level management.

This study used two types of techniques to be able to generate information. The first technique that was used to gather information was through Questionnaire. Questions were constructed based on Department Order 174 of 2016.

\section{RESULTS AND DISCUSSION} 3.1. Process of acquiring employees of selected fast-food establishments in Cabanatuan after the implementation of DOLE DO 174.

Table 1.Process of acquiring employees

\begin{tabular}{c|c|c}
\hline & Before & After \\
\hline Direct Hire & 13 & 9 \\
\hline Through Agency & 2 & 6 \\
\hline Total & 15 & 15 \\
\hline
\end{tabular}

Table 1 shows that 22 respondents answered that their workers were directly hired by the company, while 8 of them were hired through an agency. It simply means that the majority of the employers were getting their manpower through direct hiring.

About DO 174, an employee who is directly hired by the Principal is subject for regularization after its probationary period or after 6monthsunless otherwise, the employee incurred any company violations that are subject for termination. On the other hand,employees hired thru a legitimate agency are an automatic regular member of that agency.

3.2. Current employment status of selected fast-food establishments in Cabanatuan City after the implementation of DOLE DO 174.

Table 2. Current status of employment

\begin{tabular}{|c|c|c|c|c|c|c|c|c|}
\hline & \multicolumn{4}{|c|}{$\begin{array}{c}\text { BEFORE } \\
\text { Implementation of Department Order }\end{array}$} & \multicolumn{4}{|c|}{$\begin{array}{c}\text { AFTER } \\
\text { Implementation of Department Order }\end{array}$} \\
\hline & $\begin{array}{l}\text { Company } \\
\text { A }\end{array}$ & $\begin{array}{l}\text { Company } \\
\text { B }\end{array}$ & $\begin{array}{l}\text { Company } \\
\text { C }\end{array}$ & $\begin{array}{l}\text { Company } \\
\text { D }\end{array}$ & $\begin{array}{l}\text { Company } \\
\text { A }\end{array}$ & $\begin{array}{l}\text { Company } \\
\text { B }\end{array}$ & $\begin{array}{l}\text { Company } \\
\text { C }\end{array}$ & $\begin{array}{l}\text { Company } \\
\text { D }\end{array}$ \\
\hline Regular & $\sqrt{ }$ & $\sqrt{ }$ & $\sqrt{ }$ & $\sqrt{ }$ & $\sqrt{ }$ & $\sqrt{ }$ & $\sqrt{ }$ & $\sqrt{ }$ \\
\hline Agency & $x$ & $x$ & $x$ & $\sqrt{ }$ & $x$ & $\sqrt{ }$ & $\bar{x}$ & $\sqrt{ }$ \\
\hline Contractual & $\sqrt{ }$ & $\sqrt{ }$ & $\sqrt{ }$ & $\sqrt{ }$ & $\mathrm{n} / \mathrm{a}$ & $\mathrm{n} / \mathrm{a}$ & $\mathrm{n} / \mathrm{a}$ & $\mathrm{n} / \mathrm{a}$ \\
\hline
\end{tabular}


Table 2 shows that before the implementation of DOLE Department Order the status of employ ment of selected fast food establishments in Cabanatuan City, $100 \%$ of them had existing regular employees, however only company D acquired manpower thru an agency and then Company - A, $\mathrm{B}$, and $\mathrm{C}$ have existing contractualtype of employees. With the stricter inspection of DOLE several companies already regularized their employees a perfect example of this is the Company $\mathrm{A}$ and $\mathrm{C}$ wherein $100 \%$ of their employees had been already regularized by the said company on the other had Company B and D have regular employees and continue to acquire another type of employees thru legitimate manpower agency.

3.3. Duties and responsibilities of different types of empl oyees of the selected fast-food establishments in Cabanatuan City after the implementation of DOLE Do 174.

Table 3. Duties and Responsibilities of different types of employees

\begin{tabular}{c|c|c|c|c}
\hline \multirow{2}{*}{} & \multicolumn{2}{|c|}{ REGULAR } & \multicolumn{2}{c}{ AGENCY } \\
\cline { 2 - 5 } & Count & $\%$ & Count & $\%$ \\
\hline Cashiering & 10 & 66.67 & 2 & 13.33 \\
\hline Inventory Mgt & 10 & 66.67 & 2 & 13.33 \\
\hline Cooking & $\mathbf{4}$ & $\mathbf{2 6 . 6 7}$ & $\mathbf{2}$ & $\mathbf{1 3 . 3 3}$ \\
\hline Serving & $\mathbf{4}$ & $\mathbf{2 6 . 6 7}$ & $\mathbf{2}$ & $\mathbf{1 3 . 3 3}$ \\
\hline Customer Relation & 10 & 66.67 & 2 & 13.33 \\
\hline Sales Call & 10 & 66.67 & 2 & 13.33 \\
\hline Product Control & 10 & 66.67 & 2 & 13.33 \\
\hline
\end{tabular}

Table 3 shows the duties and responsibilities of different types of employees which are regular and employees from agency of selected companies which are the respondents of this research. Cooking and Serving are the task assigned to the agency as per the Service Agreement of the principal and the Manpower Agency. As stated in the DOLE DO-174 Section 5-Absolute prohibition against labor-only contracting "The contractor or sub-contractor employees recruited and placed are performing activities which are directly related to the main business operation of the principal". The result of the conducted survey shows that there are about $13.33 \%$ of employees which are under agency that performs task other than the assigned specific duties and responsibilities like Cashiering, Inventory Management, Customer Relation, sales Call and Production control.

About DOLE Department Order 174 it is clearly stated in Section 6. Other Illicit Forms of Employment Arrangements; f) requiring the contractor's/subcontractor's employees to perform functions which are currently being performed by the regular employees of the principal. In comparison to the result, it can be seen that there is duplication of work between the regular employees, parttime and agency employees certainly violating Section 6(f) of DOLE DO 174.

\subsection{Challenges encountered by the company during the} implementation of DO 174.

Table 4. Information Dissemination to workers ( $3^{\text {rd }}$ Party)

\begin{tabular}{l|l|l}
\hline Answer & Frequency & Percentage \\
\hline Yes & 8 & 53.33 \\
\hline No & 7 & 46.67 \\
\hline Total & 15 & 100.00 \\
\hline
\end{tabular}

Based on the table, there are $53.33 \%$ of the respondents who answered that they face challenges in relaying the information to $3^{\text {rd }}$ party crew while only $46.67 \%$ of the respondents answered that they are not facing challenges in relaying information to $3^{\text {rd }}$ party crew. Still, the majority of the respondents have a hard time on relaying information to $3^{\text {rd }}$ party crew. When the DO 174 was implemented, relaying of information became difficult because of the hierarchy that should be followed, and that is from Manager to Team leader then Team Leader to $3^{\text {rd }}$ Party Crew.

Before the implementation of DO 174, the practice of relaying information of Management is directly given to workers regardless of the employ ment status. With the strict execution of DO 174, the process of relaying information should include the tripartite set up (principal to agency, agency to members/employees through the Team Leader). 
Table 5. Disciplining/Correcting workers ( $3^{\text {rd }}$ Party)

\begin{tabular}{l|l|l}
\hline Answer & Frequency & Percentage \\
\hline Yes & 15 & 100.00 \\
\hline No & 0 & 0 \\
\hline Total & 15 & 100.00 \\
\hline
\end{tabular}

As shown in Table 5, 100\% of the respondents answered that their companies do not face difficulties on directly disciplining/correcting workers.

Before the implementation of DOLE DO 174, the management was directly correcting workers. When the tripartite set up was made in compliance with DOLE DO 174, selected fast food establishments experienced several problems in disciplining employees specifically the third party employees because it is inconsistently done by the Team Leader that was selected by the Agency.

Table 6. Execute performance appraisal, directing, controlling if the worker is not directly hired

\begin{tabular}{l|l|l}
\hline Answer & Frequency & Percentage \\
\hline Yes & 8 & 53.33 \\
\hline No & 7 & 46.67 \\
\hline Total & 15 & 100.00 \\
\hline
\end{tabular}

Based on Table 6, 53.33\% of the respondents said that the top level management of their company was directly involved in terms of performance appraisal, directing, controlling on those workers who are not directly hired and $46.67 \%$ of them have answered that their top-level management was not directly involved in terms of performance appraisal, directing and controlling workers who are not directly hired.

It is shown in DOLE Department Order 174 under Section 5. Absolute Prohibition against Labor-only contracting; b) the contractor or subcontractor does not exercise the right to control over the performance of the work of the employee. In comparison to the result, it clearly shows that fast-food companies had challenges in executing performance appraisal, directing and controlling workers who are not directly hired, therefore violating the article on Section 5.

\section{CONCLUSIONS AND RECOMMENDATIONS}

Based on the findings of the study, the following the researchers concluded that the majority of the employees working on fast food chains were hired directly by the companies. The fast-food establishments in
Cabanatuan City contractual employees were eliminated. Likewise, the results of this research showed that there were still duplication of work that appeared to be non-compliant of Section 6; F of DO 174 which states that "requiring the contractor's/subcontractor's employees to perform functions which are currently being performed by the regular emp loyees of the principal is declared prohibited for being contrary to the law or public policy". In accordance to the implementation of the said Department Order, relaying or giving of information needed has now became complex due to the new hierarchy that was made wherein all the information must be relayed through team leaders from cooperative which serves as the middle man, and they should be the one relaying it directly to third-party employees. With this matter, it was found out that the top level management was still directly involved in terms of performance appraisal, directing, controlling on workers who are not directly hired and in correcting/disciplining third-party employees. With this, selected fast food chains have clearly did not comply on DO 174 Section 5:B of the Absolute Prohibition against Labor-only Contracting which states that "an arrangement where the contractor or subcontractor does not exercise the right to control over the performance of the work of the employee is totally prohibited"[9].

Based on the findings and conclusions of the study, the following are thus recommended:

Conduct a follow-up research which is related with this study to further validate and monitor the consistency and compliance of fast food companies with the Department Order 174 and sustain the current and right procedure of regularizing directly hired employees. Further, there should continue practice of compliance with Depart ment Order 174 regarding the elimination of contractualization on respective companies. A thorough understanding and review of Department Order 174 shall be made by the companies to be able to make accurate decisions given available information [10] and compare it with their existing practices. Lastly, the empowerment of team leaders must be implemented. The Area coordinator from Agency should be the one responsible to study and explore the performance [11] of the perfect person qualified for the position. With the help of the top management level, credible, reliable and responsible team leaders could be developed through engaging them in training and capability buildings that will help them be competent and perfectly fit their designation. 


\section{REFERENCES}

[1] Testa, Dino Marie (May 2016). Managli, Cloey (May 2019) https://www.ecomparemo.com/info/what-youneed-to-know-about-contractualization-and-end-of-

contract/

[2] Vega, Thea Elisa (2012)

https://www.academia.edu/14701985/A SOCIAL RE PRESENTATIONS_STUDY_OF_CONTRACTUALI

ZATION?auto=download

[3] "Book Six: Labor Code of the Philippines: Presidential Decree No. 442, as Amended". www.chanrobles.com. Retrieved 2018-07-19.

[4] Artemio P. Calumpong and Lorenzo Jared J. Briones (October

http://www.zglaw.com/ zglaw/blog/2017/01/05/endin g-endo/\# ftn 1

[5] DOLE (July 2016). Department Order No. 18-A, Section 7

http://cruzmarcelo.com/2017/04/24/dole-re leases-newrules-on-contracting-and- subcontracting/

[6] Sims, Rosheic V. (March 2016) http://cas.upm.edu.ph:8080/xmlui/handle/123456789/3 $\underline{14 \text { ? show=full }}$

[7] Sicat, Gerardo (October 2016) https://www.philstar.co m/business/2016/10/12/163260 7/endo-wages-poverty-and-employ ment-labor-marketissues.

[8] Subia, G.S. (2018). Comprehensible Technique in Solving Consecutive Number Problems in Algebra. Journal of Applied Mathematics and Physics, 6,447457. https://doi.org/10.4236/jamp.2018.63041

[9] Cruz \& Tenefrancia.(2017). DOLE Releases New Rules on Contracting and Subcontracting http://cruzmarcelo.co m/2017/04/24/dole-re leases-newrules-on-contracting-and-subcontracting/

[10] Subia, GenerS. (2018). Think Like My Teacher (TLMT): ANew Method in Assessing Millennial Learners. International Journal of Arts, Humanities and Social Sciences.Volume 3. Issue 1.www.ijahss.com

[11] Subia, G. , A maranto, J. , A maranto, J. , Bustamante, J. and Damaso, I. (2019) Chess and Mathematics Performance of College Players: An Exploratory Analysis. Open Access Library Journal, 6, 1-7. doi: 10.4236/oalib. 1105195 